\title{
Fructose-induced increases in expression of intestinal fructolytic and gluconeogenic genes are regulated by GLUT5 and KHK
}

\author{
Chirag Patel, ${ }^{1}$ Veronique Douard, ${ }^{1}$ Shiyan Yu, ${ }^{2}$ Phuntila Tharabenjasin, ${ }^{1}$ Nan Gao, ${ }^{2}$ \\ and Ronaldo P. Ferraris ${ }^{1}$ \\ ${ }^{1}$ Department of Pharmacology and Physiology, New Jersey Medical School, Rutgers University, Newark, New Jersey; \\ and ${ }^{2}$ Department of Biological Sciences, School of Arts and Sciences, Rutgers University, Newark, New Jersey
}

Submitted 30 March 2015; accepted in final form 16 June 2015

Patel C, Douard V, Yu S, Tharabenjasin P, Gao N, Ferraris RP. Fructose-induced increases in expression of intestinal fructolytic and gluconeogenic genes are regulated by GLUT5 and KHK. Am J Physiol Regul Integr Comp Physiol 309: R499-R509, 2015. First published June 17, 2015; doi:10.1152/ajpregu.00128.2015.-Marked increases in fructose consumption have been tightly linked to metabolic diseases. One-third of ingested fructose is metabolized in the small intestine, but the underlying mechanisms regulating expression of fructose-metabolizing enzymes are not known. We used genetic mouse models to test the hypothesis that fructose absorption via glucose transporter protein, member 5 (GLUT5), metabolism via ketohexokinase (KHK), as well as GLUT5 trafficking to the apical membrane via the Ras-related protein in brain 11a (Rab11a)-dependent endosomes are required for the regulation of intestinal fructolytic and gluconeogenic enzymes. Fructose feeding increased the intestinal mRNA and protein expression of these enzymes in the small intestine of adult wild-type (WT) mice compared with those gavage fed with lysine or glucose. Fructose did not increase expression of these enzymes in the GLUT5 knockout (KO) mice. Blocking intracellular fructose metabolism by KHK ablation also prevented fructose-induced upregulation. Glycolytic hexokinase I expression was similar between WT and GLUT5- or KHK-KO mice and did not vary with feeding solution. Gavage feeding with the fructose-specific metabolite glyceraldehyde did not increase enzyme expression, suggesting that signaling occurs before the hydrolysis of fructose to three-carbon compounds. Impeding GLUT5 trafficking to the apical membrane using intestinal epithelial cell-specific Rab11a-KO mice impaired fructose-induced upregulation. KHK expression was uniformly distributed along the villus but was localized mainly in the basal region of the cytosol of enterocytes. The feedforward upregulation of fructolytic and gluconeogenic enzymes specifically requires GLUT5 and KHK and may proactively enhance the intestine's ability to process anticipated increases in dietary fructose concentrations.

fructolysis; glyceraldehyde; gluconeogenesis; glucose transporter protein, member 5; ketohexokinase; Ras-related protein in brain 11a; mice; small intestine

THE FRUCTOSE CONCENTRATION in human diets has increased almost 100-fold in the last 200 years $(16,33)$, and the current high rates of fructose intake are now linked to the development of the metabolic syndrome of insulin resistance, dyslipidemia, hypertension, and obesity $(32,47)$. Chronic consumption of high-fructose diets increases portal blood fructose concentrations, leading to fatty liver and perturbed liver function, as well as systemic blood fructose levels, leading to pathologies in peripheral organ systems (16). The rate of increase in portal

Address for reprint requests and other correspondence: Ronaldo P. Ferraris, Dept. of Pharmacology \& Physiology, New Jersey Medical School, 185 South Orange Ave., MSB H-621, Newark, NJ 07103 (e-mail: ferraris@njms.rutgers. edu).

http://www.ajpregu.org

0363-6119/15 Copyright @ 2015 the American Physiological Society

R499 blood fructose is directly dependent on intestinal processing of dietary fructose.

In the small intestine, glucose transporter protein, member 5 (GLUT5) is the primary fructose transporter responsible for the absorption of fructose into the cytosol. Unlike the intestinal glucose transporter sodium-dependent glucose transporter protein 1 (SGLT1), which is sodium dependent, GLUT5 transports fructose $\left(K_{\mathrm{m}}=6-14 \mathrm{mM}\right)$ across the apical membrane down a chemical gradient (5). Fructose transport in the blood from the cytosol is mediated by GLUT2 (7). Although the liver is the primary organ that metabolizes most of the ingested fructose, the small intestine strongly expresses all fructose-metabolizing enzymes and is responsible for the catabolism of $10-30 \%$ of ingested fructose $(3,19,34)$. Fructolysis is initiated by ketohexokinase (KHK, fructokinase), which converts fructose and ATP into fructose 1-phosphate and ADP, respectively. KHK has two isoforms, KHK-A and KHK-C. KHK-C has a 10-fold higher affinity for fructose $\left(K_{\mathrm{m}}=0.8 \mathrm{mM}\right)$ and is mainly responsible for its metabolism (1). Aldolase-B cleaves fructose 1-phosphate into three-carbon intermediates, dihydroxyacetone phosphate and glyceraldehyde, and the latter is then converted by triokinase into glyceraldehyde 3-phosphate, which then joins the glycolysis pathway. Because fructolysis bypasses feedback regulation controlling glycolysis upstream of glyceraldehyde 3-phosphate, fructose catabolism results in the rapid accumulation of several metabolic intermediates (49) that are thought to play a crucial role in the development of metabolic disease. KHK, aldolase-B, and triokinase mediate most of fructolysis (20). Other enzymes do not contribute significantly to fructose metabolism due to their relatively much higher $K_{\mathrm{m}}$ for fructose: hexokinase IV or glucokinase $(>100 \mathrm{mM})$, fructose dehydrogenase $(5 \mathrm{mM})$, fructose-3-phosphokinase (30 $\mathrm{mM})$, and sorbitol dehydrogenase $(100 \mathrm{mM})(15)$. The constitutive glycolytic hexokinase I has a $K_{\mathrm{m}}(\sim 2 \mathrm{mM})$ for fructose that is $\sim 50$-fold or more greater than for glucose (20). Thus, a deficiency of KHK and aldolase-B is responsible for major genetic disorders like essential fructosuria and fructose intolerance, respectively (18).

$\mathrm{KHK}-\mathrm{C}$ is strongly expressed in mouse and rat enterocytes, hepatocytes, and renal proximal tubule cells $(15,50)$, whereas KHK-A is expressed in many other tissues, but levels are vanishingly low. Like those of GLUT5 and GLUT2 (16), the intestinal- and hepatic-specific activities of KHK, aldolase-B, and triokinase increase with dietary fructose (29). Expression of GLUT5 and other fructose-responsive genes is typically regulated by luminal and not endocrine signals (45).

GLUT5 plays a vital role in regulating the entry of fructose in our body. Deletion of GLUT5 reduces by $>80 \%$ in vivo intestinal fructose absorption as well as serum fructose con- 
centration (2). Diet-induced specific increases in GLUT5 expression enhance the rate of fructose absorption and involve de novo mRNA and protein synthesis $(25,44)$. Once GLUT5 synthesis has been upregulated by dietary fructose, trafficking of GLUT5 to the apical membrane is important so transport activity matches the increased luminal fructose concentration. Ras-related protein in brain 11a (Rab11a) is an important GTPase associated with recycling endosomes critical for both endocytic and exocytic protein pathways (57). It is mainly associated with the apical recycling endosome in polarized epithelia (21), and regulates the movement of known brushborder biomarkers dipeptidyl peptidase and alkaline phosphatase to the apical membrane (46). The roles of Rab1la in regulating traffic of sugar transporters to the apical membrane and in trafficking of a transporter to the apical membrane on the regulation of enzymes mediating the catabolism of its substrate have not yet been investigated.

Because intestinal processing of dietary fructose determines portal blood fructose concentrations that, under high fructose conditions perturb liver function as well as fructose and, eventually glucose, homeostasis, we investigated the mechanisms by which dietary fructose regulates the expression of intestinal enzyme systems that metabolize this sugar. Using genetically modified mice, we tested the hypothesis that GLUT5-mediated fructose transport, KHK-mediated fructolysis, and Rab11a-mediated GLUT5 trafficking are each required for fructose to induce expression of enzymes involved in fructolysis and gluconeogenesis. Because sweet taste receptors able to sense luminal sugars and artificial sweeteners have been localized in the small intestine (36), fructose may need not enter the enterocytes for induction to occur. The role of fructose transport in fructolytic and gluconeogenic enzyme regulation was evaluated using GLUT5 knockout (KO) mice. Intracellular fructose by itself and/or its metabolites may induce expression; thus, the role of metabolism was tested using KHK-KO mice. The intracellular distribution of KHK is known for cells in the kidney and liver (15), but not for those in the small intestine; hence, we immunolocalized KHK in enterocytes. The requirement of GLUT5 trafficking to the apical membrane was investigated using enterocyte-specific, Rab11a-KO (Rab11a $\left.{ }^{\Delta I E C}\right)$ mice.

\section{MATERIALS AND METHODS}

Mice

All procedures conducted in this study were approved by the Institutional Animal Care and Use Committee, New Jersey Medical School (NJMS), Rutgers University. Tissues collected from wild-type (WT) and genetically modified $\left[\mathrm{GLUT}^{-/-}(\mathrm{KO}), \mathrm{GLUT5}^{+/-}\right.$ heterozygous $(\mathrm{HZ}), \mathrm{KHK}^{-\prime-}(\mathrm{KO}, \mathrm{A}$ and $\mathrm{C}$ isoforms both ablated globally)] $\mathrm{KHK}^{+\prime-}(\mathrm{HZ})$ and Rab11 $\mathrm{a}^{\Delta \mathrm{IEC}}$ mice were used. Rab11a ${ }^{\Delta I E C}$ mice were lacking Rab11a protein only in the intestinal epithelial cells, since global Rab11a deletion is fatal in utero (57). GLUT5-KO (from Jian Zuo, St. Jude's Children's Research Hospital), KHK-KO (from Richard Johnson, University of Colorado), and WT (C57BL/6) mice were housed in the Comparative Medicine Resources (CMR) facility of NJMS, under a temperature-controlled room with a 12:12-h light-dark cycle and had free access to water and a regular nonpurified diet (Purina Mills, Richmond, IN). Male and female KO mice (GLUT5 and KHK) were mated in the CMR. Rab11 $\mathrm{a}^{\Delta \mathrm{IEC}}$ mice were housed in the Research Animal Facility of Newark College of Arts and Sciences, Rutgers University, in a temperature-controlled environment with a 12:12-h light-dark cycle. Same-age WT (C57BL/6 for KHK-KO and GLUT5-KO, 129/B6 for Rab11 $\mathrm{a}^{\Delta \mathrm{IEC}}$ ) mice were used as a control in all experiments involving genetically modified mice (GLUT5-KO, KHK-KO, or Rab11a ${ }^{\Delta \mathrm{IEC}}$ ). Generation and phenotypic description of GLUT5-KO (55), KHK-KO (15), and Rab11a ${ }^{\Delta I E C}(57)$ mice was reported in detail previously. Previously validated primer sequences $(15,55,57)$ confirmed genetic modifications in these mice. GLUT5-KO and KHK-KO mice showed normal phenotypes. Rab11 $\mathrm{a}^{\Delta \mathrm{IEC}}$ mice exhibited previously reported runting and growth retardation. Rab11 $\mathrm{a}^{\Delta \mathrm{IEC}}$ were used, before weaning, at 18 days of age, since there was high mortality in postweaning Rab11a ${ }^{\Delta I E C}$ mice (57).

\section{Experimental Design}

Role of metabolism and intracellular trafficking in the regulation of fructolytic and gluconeogenic genes. In study I, 4- to 5-wk-old WT, GLUT5-HZ, and GLUT5-KO mice were randomly divided in three groups and then gavaged, under light anesthesia, with $30 \%$ lysine (nonsugar control), glucose (sugar control), or fructose $(2 \mathrm{ml} / 100 \mathrm{~g}$ body wt, $\sim 0.3 \mathrm{ml} /$ mouse) solution two times a day for 2.5 days $(n=$ $6 /$ genotype and diet). After gavage feeding, mice were observed for a few minutes for any abnormal behavior and then immediately returned to the cages where they resumed normal activity and ad libitum feeding of chow. Body weight and food intake were measured daily. Mice were killed $4 \mathrm{~h}$ after the last (5th) gavage in the morning of the 3rd day. The proximal part $(6-8 \mathrm{~cm})$ of the small intestine was scraped and snapped frozen in liquid nitrogen for future analyses by real-time PCR and Western blots.

Study II was comprosed of three experiments. In the first, the same protocol as in the first study was followed, except that WT, KHK-HZ, and KHK-KO mice were used. In the second experiment, 4- to 5 -wk-old WT mice ( $n=6$ /group) were anesthetized and then gavaged with $15 \%$ glucose, fructose, or glyceraldehyde solution $(2 \mathrm{ml} / 100 \mathrm{~g})$ as previously described. A concentration of $15 \%$ was selected, since preliminary work showed that $30 \%$ glyceraldehyde was not tolerated well. The third experiment was the same as the second, except that KHK-KO mice were used because these are expected to have less endogenous glyceraldehyde and therefore are potentially more sensitive to glyceraldehyde feeding.

In study III, Rab11 $\mathrm{a}^{\Delta \mathrm{IEC}}$ and WT (18-day-old) littermates were each randomly separated into two groups ( $n=4 /$ group) and gavaged with either $30 \%$ glucose or fructose solutions as previously described.

\section{Real-Time PCR}

Total RNA was extracted from the small intestinal mucosa of mouse using TRIzol reagent (Invitrogen, Carlsbad, CA). An RNeasy mini kit (Qiagen, Valencia, CA) was used for purification of the RNA. The cDNA was generated using $5 \mu \mathrm{g}$ of purified RNA by RT-PCR using a thermal cycler (i-Cycler; Bio-Rad, Hercules, CA) with a Super Script III Reverse Transcriptase kit (Invitrogen). Real-time PCR using Mx3000P (Stratagene, La Jolla, CA) was used to analyze cDNA as described in our earlier work (50). The Roche primer design software (http://www.rocheapplied-science.com) was used to design various primers that were purchased from Integrated DNA Technologies (IDT, Coralville, IA). Elongation factor $1 \alpha(\mathrm{Ef} 1 \alpha)$ was used as a housekeeping gene to correct for potential variability in loading. Previously published primer sequences for EF1 $\alpha$ and KHK are listed in Tharabenjasin et al. (50). Primers for the following genes are as follows (forward, reverse, annealing temperature): aldolase-B: 5'-AATAGGGACCAGCCCATTCT-3', 5'-CTTCCAGCCTTGCTATCCAA-3', 60 ${ }^{\circ} \mathrm{C}$; triokinase: 5'-GTGTTTGCCTCTCCTCCTGT, 5'-AGCCGATCCCCAGTGTAGTT- $3^{\prime}$, 56 ${ }^{\circ}$; fructose-1,6-bisphosphatase (F-1,6- $\left.P_{2}\right)$ : 5'-TATACCCCGCCAACAAGAAA-3'， 5'-AAGCTATGGGGTTGACTCA-3'，58 ${ }^{\circ} \mathrm{C}$; glucose-6phosphatase (G-6-Pase): 5'-GGCTCACTTTCCCCATCAGG-3', 5' ATCCAAGTGCGAAACCAAACAG- $3^{\prime}, 54^{\circ} \mathrm{C}$; hexokinase I: $5^{\prime}$ ATGTGTGTGCCACTCCAGAC-3'， 5'-GACCCGGAAGTTTGTTCCTC- $3^{\prime}, 54^{\circ} \mathrm{C}$. 
Western Blot Analysis

Western blots were performed using protein $(70 \mu \mathrm{g})$ extracted from intestinal mucosal scrapes, following methods previously described (10). Intestinal proteins were separated using a precast $4-20 \%$ Tris $\cdot \mathrm{HCl}$ gel (Bio-Rad), transferred to a nitrocellulose membrane, and analyzed with primary antibodies against KHK (1:500; Sigma Aldrich, St. Louis, MO). The KHK antibody used in this study can theoretically detect both isoforms of KHK (KHK-A and KHK-C), although KHK-A is not expressed in small intestine. All membranes were subsequently stripped and reprobed with primary antibody against the housekeeping protein $\beta$-actin (1:1,000; Millipore International).

\section{Immunohistochemistry}

A jejunal segment $(2 \mathrm{~cm})$ from WT and Rab11 $\mathrm{a}^{\Delta \mathrm{IEC}}$ mice fed fructose was excised and immediately fixed in fresh $4 \%$ paraformaldehyde solution at room temperature overnight. After fixation, tissue samples were embedded in paraffin and sectioned $(\sim 5 \mu \mathrm{m})$. Tissue sections were incubated with primary antibody \{rabbit anti-rat GLUT5 [1:200 (a generous gift from Chris Cheeseman, University of Alberta); Millipore]\}, goat antihuman villin (1:200; Santa Cruz), and with the nuclear stain Topro3 (1:1,000; Life Technology) in $1 \times$ phosphate-buffered saline (PBS) containing 2\% donkey serum (Sigma), 2\% bovine serum albumin (Sigma), and 0.1\% Triton X-100 (Sigma) overnight at $4^{\circ} \mathrm{C}$ in a dark humidified chamber. Sections were then washed using PBS three times at $15 \mathrm{~min}$ each. Fluorochromelabeled secondary antibodies [Alexa 546-conjugated donkey antirabbit IgG (1:500; Life Technology)] for GLUT5 and Alexa 488-conjugated rabbit antigoat IgG (1:500; Life Technology) for villin were applied for $1 \mathrm{~h}$ at room temperature. After incubation, tissues were washed with PBS buffer and mounted with fluorescent mounting medium (Dako, North America). In a separate experiment, $2 \mathrm{~cm}$ of duodenum from WT and KHK-KO mice were excised and fixed in paraformaldehyde as mentioned previously. Tissue sections were blocked in $1 \%$ normal goat serum (NGS) as mentioned earlier and then incubated in primary antibody chicken anti-KHK (1:200; SigmaAldrich) in $1 \%$ NGS and then processed as described above. The stained sections from both experiments were examined at $\times 20,40$, and 60 magnification with a laser-scanning confocal microscope (Nikon Eclipse Ti; NIS-Elements AR 4.11.00 program). All images compared were obtained with the same settings of the microscope.

\section{Uptake Assay}

Fructose and glucose uptake rates in the jejunum were measured by the everted sleeve method described in detail previously (25). Briefly, a $1-\mathrm{cm}$ jejunal segment was everted and mounted on a grooved steel rod and preincubated for $5 \mathrm{~min}$ at $37^{\circ} \mathrm{C}$ in Ringer solution. The sleeves were then incubated in an oxygenated solution containing $50 \mathrm{mM}$ of either $\mathrm{D}-\left[{ }^{14} \mathrm{C}\right]$ glucose for $1 \mathrm{~min}$ or D- $\left[{ }^{14} \mathrm{C}\right]$ fructose for $2 \mathrm{~min}$. L- $\left[{ }^{3} \mathrm{H}\right]$ glucose was used to correct for adherent fluid and passive diffusion of glucose or fructose.

\section{Statistical Analyses}

Data are presented as means \pm SE. A two-way ANOVA analyzed the simultaneous effects of nutrient solution and genotype on gene expression ( $P$ values are mentioned in the text). Differences were considered significant at $P \leq 0.05$. If an initial two-way ANOVA indicated a significant effect of nutrient solution and/or genotype, a one-way ANOVA followed by least-significant difference test (STATVIEW; Abacus Concepts) was used to analyze the data and display significant differences among means in Figs. 1-10. A one-way ANOVA was used when comparing initial and final body weights, and in the experiments with glyceraldehyde where only nutrient solution effects were analyzed.

\section{RESULTS}

\section{Food Consumption and Body Weight}

All mice in our experiments had ad libitum access to normal diet during the 2.5 days of gavage feeding of various substrates. Food intake and body weight were thus normal and virtually the same in all mice, except for those in study III (Table 1). Growth of adult mice was minimal over 3 days. Deletion of Rab11a from the intestinal cells had profound effects on growth. Mean initial and final body weights were different $(P<0.04)$. This was expected since the phenotype of Rab11a $\mathrm{a}^{\Delta \text { IEC }}$ mice is characterized by runting and slower growth compared with WT mice (57). Feeding rate was not measured in study III, since mice were returned to their dams after gavage feeding.

\section{Effect of GLUT5 Deletion on Fructose-Induced Expression of Fructolytic and Gluconeogenic Genes}

Deletion of GLUT5 abolished $(0.02 \pm 0.20)$ facilitated fructose transport compared $(P<0.0001)$ with that in WT mice $\left(1.9 \pm 0.2 \mathrm{nmol} \cdot \mathrm{mg}^{-1} \cdot \mathrm{min}^{-1}\right)$. Mean relative GLUT5

Table 1. Body weights and food consumption rates of mice

\begin{tabular}{|c|c|c|c|c|}
\hline Genotype & $\begin{array}{l}\text { Gavage } \\
\text { Treatment }\end{array}$ & $\begin{array}{l}\text { Initial Body } \\
\text { Wt, g }\end{array}$ & $\begin{array}{c}\text { Final Body } \\
\text { Wt, g }\end{array}$ & $\begin{array}{c}\text { Food Consume } \\
\text { g/day }\end{array}$ \\
\hline & \multicolumn{4}{|c|}{ Study I } \\
\hline \multirow[t]{3}{*}{ WT } & Lysine & $20.3 \pm 0.5$ & $21.5 \pm 0.7$ & $5 \pm 0.2$ \\
\hline & Glucose & & & $4.9 \pm 0.3$ \\
\hline & Fructose & & & $5.2 \pm 0.3$ \\
\hline \multirow[t]{3}{*}{ GLUT5-HET } & Lysine & & $21.6 \pm 0.9$ & $4.9 \pm 0.1$ \\
\hline & Glucose & & & $5.1 \pm 0.2$ \\
\hline & Fructose & & & $5.3 \pm 0.1$ \\
\hline \multirow[t]{3}{*}{ GLUT5-KO } & Lysine & & $21.4 \pm 0.2$ & $4.9 \pm 0.3$ \\
\hline & Glucose & & & $5.2 \pm 0.3$ \\
\hline & Fructose & & & $5 \pm 0.1$ \\
\hline
\end{tabular}

Study II, Experiment 1

\begin{tabular}{|c|c|c|c|c|}
\hline \multirow[t]{3}{*}{ WT } & Lysine & $20.2 \pm 0.8$ & $21.4 \pm 0.7$ & $4.9 \pm 0.08$ \\
\hline & Glucose & & & $4.9 \pm 0.3$ \\
\hline & Fructose & & & $5.2 \pm 0.2$ \\
\hline \multirow{3}{*}{ KHK-HET } & Lysine & & $21.3 \pm 0.8$ & $5 \pm 0.2$ \\
\hline & Glucose & & & $5.2 \pm 0.4$ \\
\hline & Fructose & & & $5.3 \pm 0.3$ \\
\hline \multirow{3}{*}{ KHK-KO } & Lysine & & $21.5 \pm 1$ & $5.1 \pm 0.5$ \\
\hline & Glucose & & & $5.4 \pm 0.4$ \\
\hline & Fructose & & & $5.1 \pm 0.09$ \\
\hline
\end{tabular}

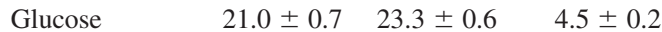

Fructose $\quad 5.0 \pm 0.3$

Glyceraldehyde $\quad 4.9 \pm 0.4$

Study II, Experiment 3

$\begin{array}{lllll}\text { KHK-KO } & \text { Glucose } & 19.7 \pm 0.5 & 21.0 \pm 0.4 & 4.6 \pm 0.2 \\ & \text { Fructose } & & & 4.7 \pm 0.1 \\ & \text { Glyceraldehyde } & & & 5.0 \pm 0.4\end{array}$

Study III

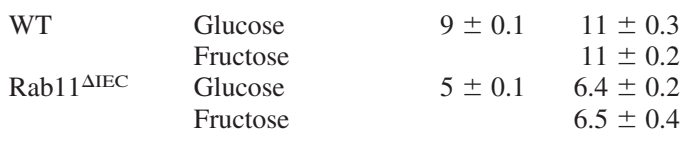

Values are means \pm SE. WT, wild type; GLUT5, glucose transporter protein, member 5; HET, heterozygous; KO, knockout; KHK, ketokexokinase. 

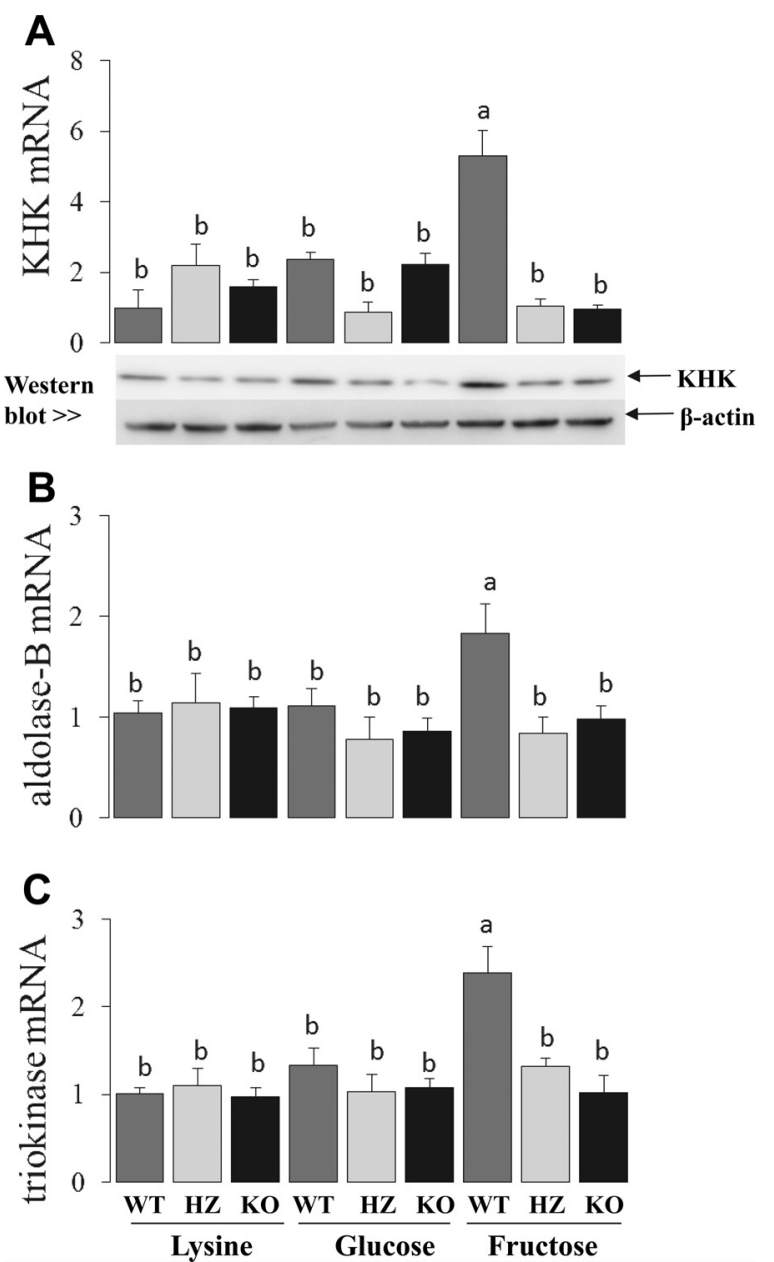

Fig. 1. Effect of glucose transporter protein, member 5 (GLUT5) deletion on fructose-induced expression of fructolytic enzymes. The effect of fructose feeding and GLUT5 deletion on expression of various genes involved in fructolysis was evaluated by determining levels of mRNA from the jejunum of wild-type (WT), GLUT5 heterozygous (HZ), or GLUT5 knockout (KO) mice gavaged with $30 \%$ lysine, glucose, or fructose, two times a day at 0.3 $\mathrm{ml} /$ mouse. Otherwise, all mice had ad libitum access to chow. Jejunal mRNA expression of ketohexokinase (KHK) $(A)$, aldolase-B $(B)$, and triokinase $(C)$. KHK protein expression was analyzed by Western blot $(n=2, A$ shows a representative blot) with $\beta$-actin as reference. Results were normalized to those in WT mice gavaged with lysine. Bars are means \pm SE $(n=4-6)$, and those with different superscript letters are statistically different $(P<0.05)$ from each other as analyzed by 1-way ANOVA followed by least-significant difference (LSD) analysis. Bars that share the same superscript letter are the same. Detailed statistical analyses are described in the text. Upregulation of fructolytic enzymes requires transapical fructose transport mediated by GLUT5 in WT mice.

mRNA level in WT was $1.0 \pm 0.2$, and there was none in the KO mice. The abrogation of fructose transport affected the response of fructolytic and gluconeogenic genes. By two-way ANOVA, the mRNA expression of KHK, aldolase-B, and triokinase varied with fructose feeding $(P \leq 0.04$ for all three genes) and GLUT5 deletion $(P \leq 0.03)$ (Fig. $1, A, B$, and $C$ ). There was also a significant interaction between fructose feeding and GLUT5 deletion $(P \leq 0.04)$, implying that the fructose effect depended on the genotype. In WT mice, fructose feeding increased KHK expression by 3.5 -fold and aldolase-B as well as triokinase by two-fold ( $P \leq 0.005$ for all three enzymes). This fructose-induced increase in mRNA expression of genes specific to fructose metabolism was clearly prevented in GLUT5-HZ and GLUT5-KO mice. The mRNA expression of KHK, aldolase-B, and triokinase was similar in the small intestine of WT, GLUT5-HZ, and GLUT5-KO mice when gavaged with either lysine or glucose $(P \geq 0.2$ in all cases), suggesting that baseline mRNA levels of these genes were independent of genotype, and did not compensate for GLUT5 ablation. Changes in the protein expression of KHK correlated with corresponding mRNA levels (Fig. 1A).

Fructose feeding $(P \leq 0.001)$ and GLUT5 deletion $(P \leq$ 0.02 ) affected the mRNA expression of the gluconeogenic genes F-1,6- $P_{2}$ and G-6-Pase $\left(P_{\text {interaction }}<0.01\right)$. Fructose increased in WT, but not in GLUT5-HZ and GLUT5-KO, mice the mRNA expression of F-1,6- $P_{2}$ and G-6-Pase by more than threefold (Fig. 2, $A$ and $B$ ). There was no significant difference in levels of these enzymes in GLUT5-KO and WT mice fed lysine and glucose ( $P \geq 0.6$ for both enzymes), suggesting that GLUT5 deletion did not affect constitutive mRNA expression of gluconeogenic genes. The finding that GLUT5 deletion abolishes the ability of dietary fructose to regulate fructolytic and representative gluconeogenic genes suggests that fructose transport is likely required for fructose-induced regulation. The effect of fructose on these genes is specific, since it has no effect on intestinal hexokinase I expression. By two-way ANOVA, hexokinase expression did not change with genotype $(P=0.30)$ and with $\operatorname{diet}(P=0.50)$, and there was no interaction $(P=0.90)$. Mean hexokinase mRNA expression for the GLUT5-KO experiment was as follows: WT mice
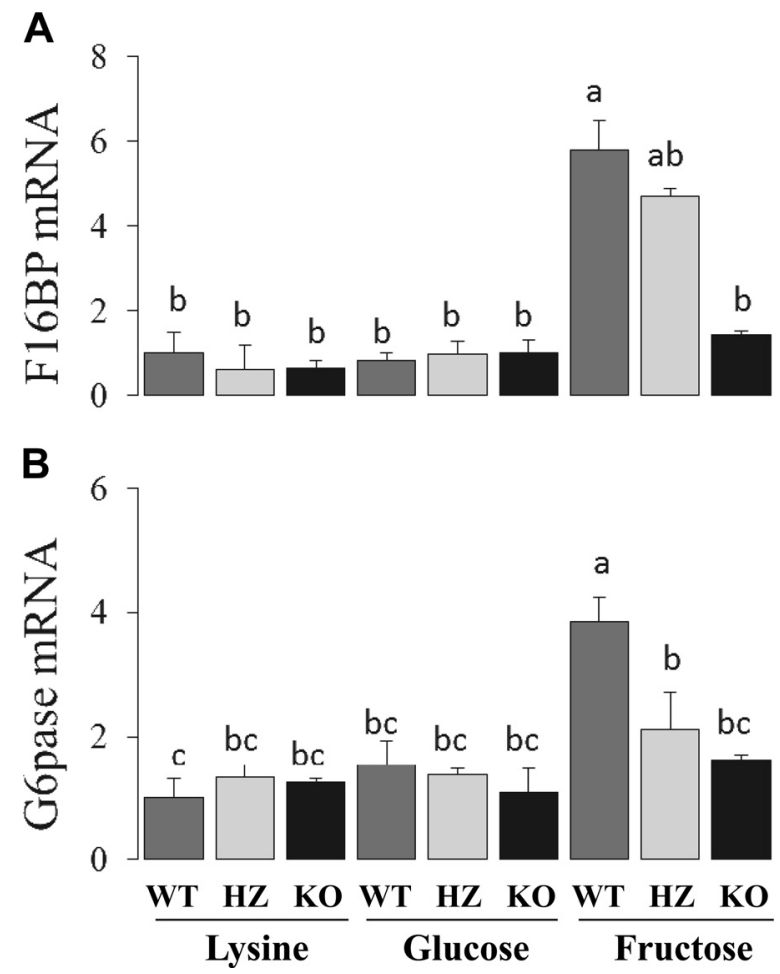

Fig. 2. Effect of GLUT5 deletion on fructose-induced expression of representative genes in gluconeogenesis. Jejunal mucosa were obtained from WT, GLUT5-HZ, or GLUT5-KO mice gavaged with lysine, glucose, or fructose. Levels of mRNA of fructose-1,6-bisphosphatase (F-1,6- $\left.P_{2}, A\right)$ and glucose-6phosphatase (G-6-Pase, $B$ ). Bars, normalization, and analysis are described in Fig. 1. Upregulation of genes in gluconeogenesis requires GLUT5-mediated fructose uptake. 

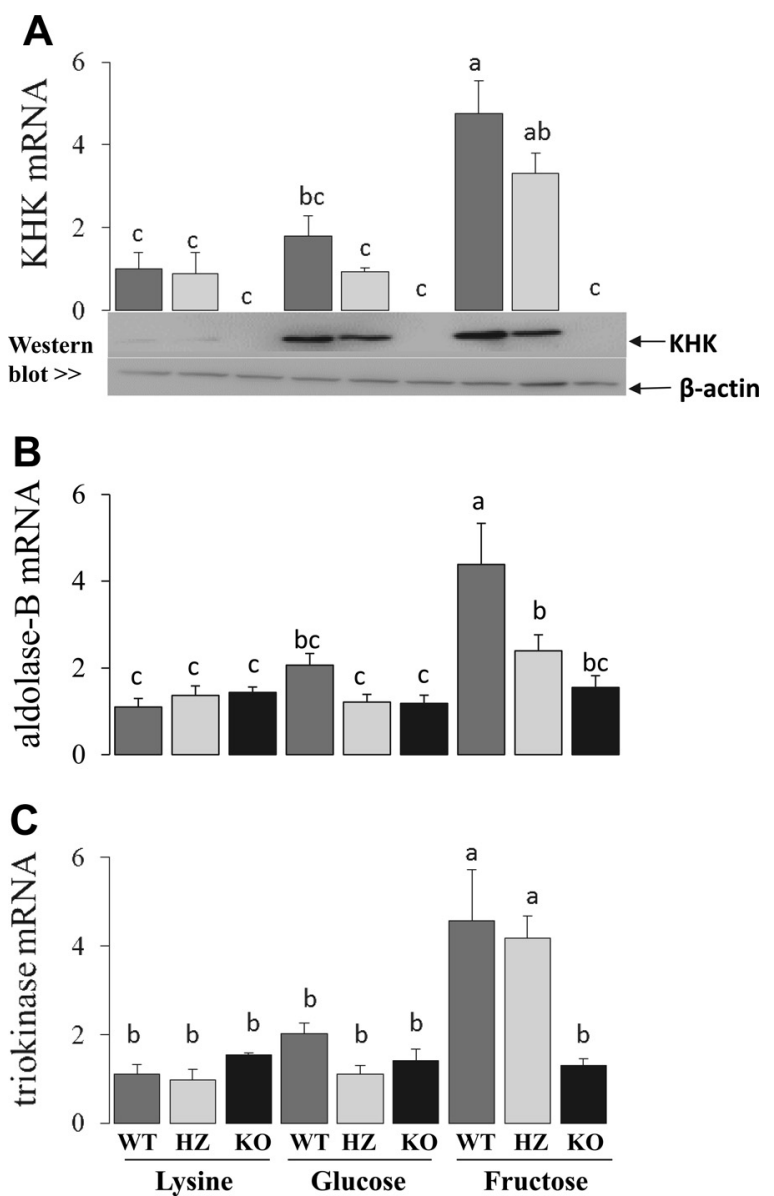

Fig. 3. Effect of KHK deletion on fructose-induced expression of fructolytic genes. The effect of fructose feeding and KHK deletion on mRNA and protein expression of KHK $(A)$, aldolase-B $(B)$, and triokinase $(C)$ in the jejunal mucosa of WT, KHK-HZ, or KHK-KO mice gavaged with lysine, glucose, or fructose. Bars, normalization, and analysis are as explained in Fig. 1. Upregulation of enzymes involved in fructolysis requires KHK-mediated metabolism.

gavaged with lysine (lysine-WT) $=1.0 \pm 0.1$, lysine- $\mathrm{HZ}=1.3 \pm$ 0.4 , lysine-KO $=1.0 \pm 0.1$, glucose-WT $=0.7 \pm 0.2$, glucose- $\mathrm{HZ}=1.0 \pm 0.2$, glucose- $\mathrm{KO}=1.0 \pm 0.1$, fructose-WT $=0.7 \pm 0.1$, fructose- $\mathrm{HZ}=1.0 \pm 0.2$, and fructose- $\mathrm{KO}=0.7 \pm 0.2$.

\section{Effect of KHK Deletion on Fructose-Induced Gene Expression}

Fructose feeding $(P<0.0001-0.01)$ and KHK deletion $(P<0.0001-0.007$, by 2 -way ANOVA) significantly affected the mRNA expression of KHK, aldolase-B, and triokinase (Fig. 3, A, $B$, and $C$ ). Significant interactions suggested that genotype modulated the effect of fructose on expression of these three genes $\left(P_{\text {interaction }}<0.003-0.010\right)$. In WT mice, fructose feeding increased by four- to sevenfold mRNA expression of KHK, aldolase-B, and triokinase. Protein expression of KHK corresponded with its mRNA levels. As expected, no KHK transcript was detected in KHK-KO mice while KHK-HZ mice had 35\% less mRNA than WT. Fructose-induced increases in aldolase-B and triokinase were clearly prevented by KHK ablation, which did not affect the basal mRNA expression of these genes $(P \geq 0.9$ in all cases) in lysine- and glucose-fed mice. There were no compen- satory changes in aldolase-B and triokinase mRNA levels in KHK-KO mice.

Fructose feeding $(P<0.001)$ and KHK deletion $(P=0.001)$ markedly affected the mRNA expression of F-1,6- $P_{2}$ (Fig. $4 A$ ). These treatments also affected G-6-Pase expression $(P=0.001$ and 0.02 , respectively, Fig. $4 B$ ). The effect of fructose feeding on F-1,6- $P_{2}$, but not G-6-Pase, mRNA expression was genotype dependent $\left(P_{\text {interaction }}<0.005\right)$. In WT but not in KHK-KO mice, fructose feeding increased by four- to fivefold the mRNA expression of F-1,6- $P_{2}$ and G-6-Pase; thus, upregulation of these gluconeogenic genes is dependent on KHKmediated metabolism. There was no significant difference in mRNA expression of F-1,6- $P_{2}$ and G-6-Pase in WT, KHK-HZ, and KHK-KO mice gavaged with either lysine or glucose $(P \geq$ 0.4 in all cases for both enzymes), suggesting that deletion of KHK did not affect their basal mRNA expression.

These fructose-induced increases in expression are specific to fructolytic and gluconeogenic genes because levels of hexokinase I did not change with genotype $(P=0.20)$ and with $\operatorname{diet}(P=0.09)$, with no interaction $(P=0.30)$. Mean hexokinase mRNA for the KHK-KO experiment was as follows: lysine-WT $=1.0 \pm 0.2$, lysine- $\mathrm{HZ}=1.1 \pm 0.3$, lysine- $\mathrm{KO}=$ $1.3 \pm 0.4$, glucose-WT $=0.8 \pm 0.3$, glucose- $\mathrm{HZ}=0.6 \pm 0.3$, glucose-KO $=1.1 \pm 0.2$, fructose-WT $=0.5 \pm 0.1$, fructose- $\mathrm{HZ}=0.8 \pm 0.3$, and fructose- $\mathrm{KO}=0.6 \pm 0.2$.

\section{Effect of Glyceraldehyde Feeding on Fructose-Induced Gene Expression}

WT mice. Fructose feeding $(P \leq 0.04$ for all three genes, by one-way ANOVA) increased the mRNA expression of KHK, aldolase-B, and triokinase, but glucose or glyceraldehyde
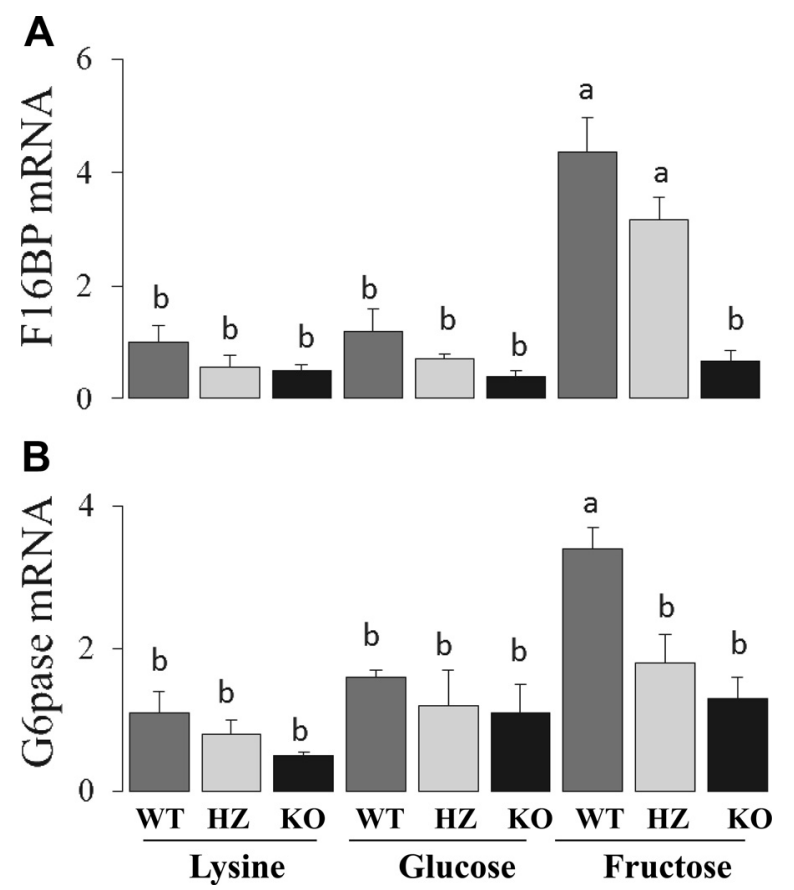

Fig. 4. Effect of KHK deletion on fructose-induced expression of gluconeogenic genes. Levels of mRNA expression of F-1,6- $P_{2}(A)$ and G-6-Pase $(B)$ in the jejunal mucosa of WT, KHK-HZ, or KHK-KO mice gavaged with lysine, glucose, or fructose. Bars, normalization, and analysis are as explained in Fig. 1. Upregulation of gluconeogenic genes requires KHK-mediated metabolism because fructose gavage did not induce F-1,6- $P_{2}$ and G-6-Pase expression in $\mathrm{KO}$ mice. 

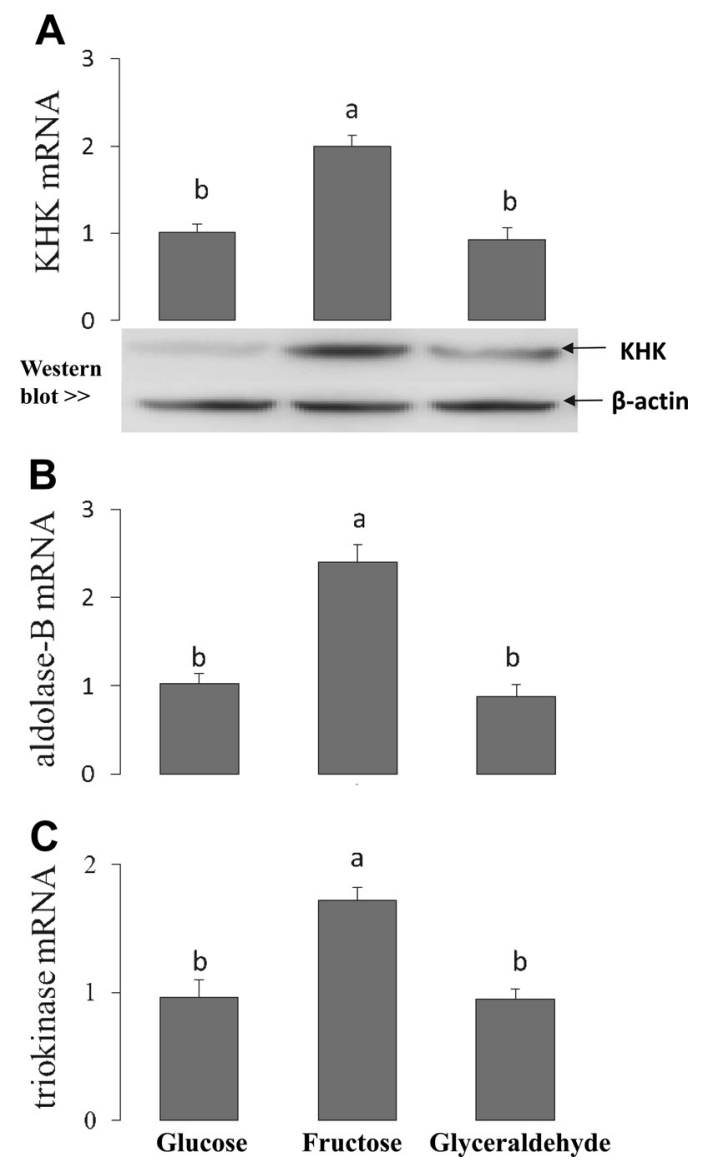

Fig. 5. Effect of feeding a fructolytic intermediate on expression of fructolytic genes in WT mice. The mRNA expression of KHK $[A$, with a Western blot $(n=2)$ depicting corresponding protein levels], aldolase-B $(B)$, and triokinase $(C)$ in the jejunal mucosa of WT mice gavaged with $15 \%$ glucose, fructose, or glyceraldehyde two times a day at $0.3 \mathrm{ml} /$ mouse that otherwise had ad libitum access to chow. Results were normalized to those in mice gavaged with glucose. Bars are means \pm SE $(n=4-6)$, and those with different superscript letters are statistically different $(P<0.05)$ from each other as determined by 1-way ANOVA. Glyceraldehyde, unlike fructose, does not induce genes coding for fructolytic enzymes.

feeding did not (Fig. 5, $A, B$, and $C$ ). The reason for the modest effect of fructose feeding in this experiment relative to those in previous experiments was probably the reduced fructose dose (15\% compared with the previously used $30 \%$ ). Fructose also increased the protein expression of KHK. The mRNA expression of gluconeogenic genes F-1,6- $P_{2}$ and G-6-Pase in mice fed glucose and glyceraldehyde was also less compared with those fed fructose $(P \leq$ 0.04 in all cases, Fig. 6, $A$ and $B$ ). These results clearly suggest that glyceraldehyde, despite being a fructose-specific metabolite, failed to induce the expression of fructolytic and gluconeogenic genes in WT mice.

KHK-KO mice. The mRNA expression of aldolase-B and triokinase as well as F-1,6- $P_{2}$ and G-6-Pase (data not shown) was each independent of $\operatorname{diet}(P \geq 0.7$ in all cases), indicating that glyceraldehyde could not induce fructose-responsive genes in the KHK-KO mice. These results also confirmed previous findings that fructose metabolism is required for fructose to induce various genes involved in fructolysis as well as in gluconeogenesis.

\section{Effect of Rablla Deletion on Fructose-Induced Expression}

Although there was no significant difference in GLUT5 mRNA expression between the small intestines of WT (relative expression: $1.0 \pm 0.1)$ and $\operatorname{Rab} 11 \mathrm{a}^{\Delta \mathrm{IEC}}(0.7 \pm 0.2)$ mice $(P=$ 0.2 ), enterocytes without Rab11a have less GLUT5 in the apical membrane (Fig. 7, $A-G$ ). Thus, fructose transport rate in WT mice was $2.50 \pm 0.53(P=0.02)$ greater than that in Rab11a ${ }^{\Delta I E C}$ mice. In contrast, glucose transport tended to be similar (ratio between rate in WT and that in Rab11 ${ }^{\mathrm{AIEC}}$ mice $=$ $1.50 \pm 0.42, P>0.05)$. Rab11a deletion $(P \leq 0.04)$ and fructose feeding $(P \leq 0.005$ for all three genes, by two-way ANOVA) affected mRNA expression of KHK, aldolase-B, and triokinase. In WT mice, fructose feeding increased mRNA expression of KHK, aldolase-B, and triokinase by two- to threefold relative to those mice fed glucose (Fig. 8, $A, B$, and C). The fructose-induced increase was prevented in Rab11a ${ }^{\Delta \mathrm{IEC}}$ mice. There was no significant difference in mRNA expression of KHK, aldolase-B, and triokinase between WT and Rab11a ${ }^{\Delta I E C}$ mice fed glucose ( $P \geq 0.6$ for the three genes), so their baseline expression was not affected by Rab11a ablation. Fructose feeding $(P \leq 0.03)$ and Rab11a deletion $(P \leq 0.01$, Fig. 9) also had significant effects on mRNA expression of F-1,6- $P_{2}$ and G-6-Pase. Fructose feeding, which significantly increased the mRNA expression of F-1,6- $P_{2}$ and G-6-Pase in WT mice, was ineffective in Rab11a ${ }^{\Delta I E C}$ mice. These results indicate that prevention of GLUT5 trafficking to the apical membrane inhibits fructose-induced gene expression.

\section{Intracellular Location of $\mathrm{KHK}$}

We have previously shown that KHK distribution tended to be homogeneous among enterocytes along the crypt-villus axis (50). In renal proximal tubules, KHK expression was greater in the medulla than in the cortex (38). Although villus location had no effect on its expression, KHK seems to be concentrated
A

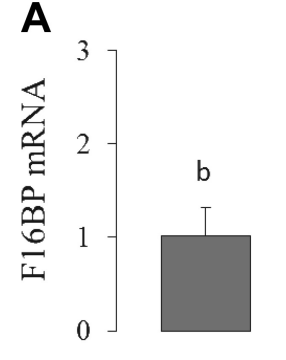

B

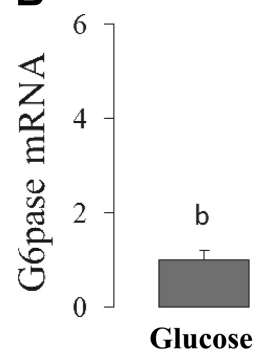

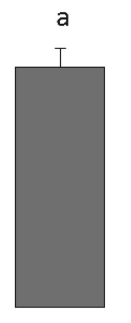
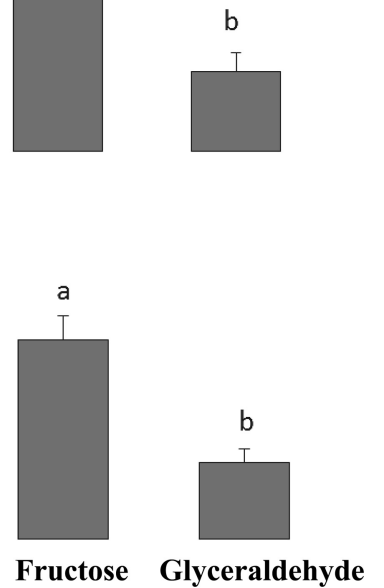

Fig. 6. Effect of glyceraldehyde on gluconeogenic genes in WT mice. The mRNA expression of F-1,6- $P_{2}(A)$ and G-6-Pase $(B)$. Bars, normalization, and analysis are as explained in Fig. 5. Glyceraldehyde, unlike fructose, does not induce gluconeogenic genes in KHK-KO mice. 

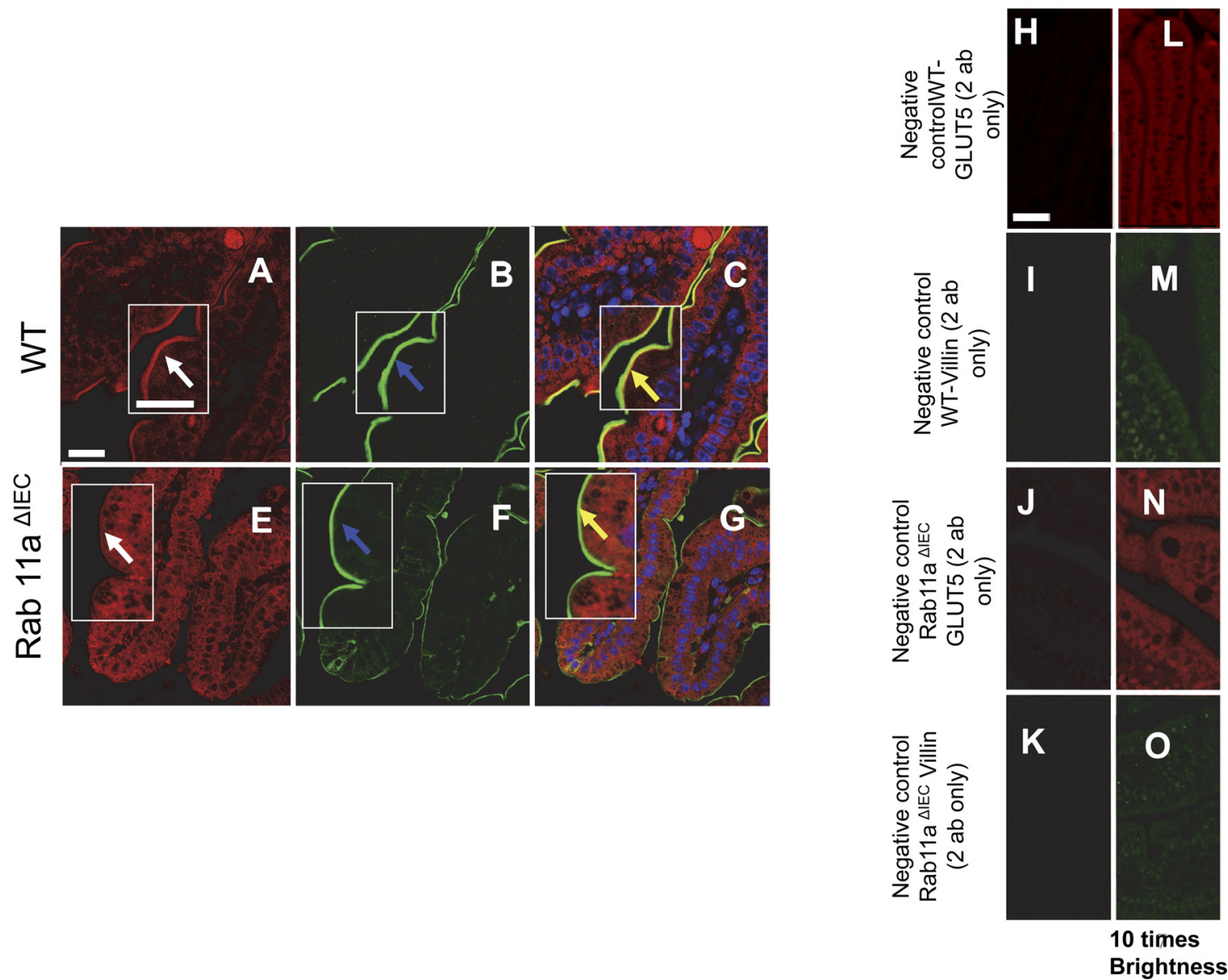

Fig. 7. Effect of Ras-related protein in brain 11a (Rab11a) deletion on GLUT5 trafficking. In WT mice, GLUT5 was clearly present in the apical membrane (A). In contrast, GLUT5 was absent in the apical membrane of Rab11 $\mathrm{a}^{\mathrm{IIEC}}$ mice $(E)$. Merged panels in $G$ but not $C$ reflect mainly green immunofluorescence from villin $\left(B\right.$ and $E$ ). $F$ : villin expression was similar in Rab11a ${ }^{\Delta \mathrm{IEC}}$ and WT mice. Arrow in $C$ shows yellow overlap of green and red fluorescence. Thus, the absence of Rab11a from intestinal epithelial cells prevents most GLUT5 from being inserted in the apical membrane, reducing rates of fructose uptake. White scale bar, $20 \mu \mathrm{m}$ (inset $=20 \mu \mathrm{m})$. Negative controls were incubated with secondary antibodies only $(H-K)$. Brightness was increased by 10 -fold in $L-O$ to show absence of binding by the secondary antibody.

in the basolateral region of the cytosol, below the basal, elongated nuclei of enterocytes (Fig. 10, $A-C$ ) facing the basolateral membrane. At higher magnification, the greater concentration of KHK in the basal region is observed in cells near the villus tip as well as in the mid and lower villus regions (Fig. 10, $D-F$ ).

\section{DISCUSSION}

\section{GLUT5 Is Required for Induction of Fructolytic and Gluconeogenic Genes}

Signals from T1R2/T1R3 receptors in the apical mucosal membrane that sense but do not absorb luminal sugars in mammalian intestine $(36,56)$ upregulate SGLT1 and may also directly stimulate expression of fructolytic and gluconeogenic genes as part of an adaptation to a sweeter diet. Because fructose-induced increases in the expression of these genes are abrogated in GLUT5-KO mice, potential signaling from these sweet receptors is either insufficient or unrelated to fructose metabolism. In contrast, transport via GLUT5 is essential for fructose-induced upregulation of intestinal fructolysis and gluconeogenesis, indicating that contributions of other intestinal GLUTs that can potentially transport fructose [GLUTs $2,7,8$, and $12(6,14,27)]$ are also insufficient. In the rat brain, fructose dose dependently upregulated the expression of GLUT2 and of GLUT5 transporters, leading to increases in KHK levels and in pyruvate as well as ATP production (54).

\section{Fructose Metabolism Is Required for Induction}

Although fructose is now a significant constituent of diets worldwide, regulation of intestinal fructolytic enzymes by its substrate has only been studied by Crouzoulon and Korieh (9) who showed that adaptive increases in KHK, aldolase-B, and triokinase activities last for several days even after fructose is removed from the diet. Chronic consumption of high-fructose diets increases KHK expression in rat kidney (8) as well as in the liver of female rats (51). In Caco-2 cells, a glucosedependent G-6-Pase mRNA increase is strictly regulated by glucose metabolism (30). Here we show that fructose must be metabolized by KHK for upregulation to occur. It is not clear whether further catabolism of the KHK product fructose 1-phosphate by aldolase- $\mathrm{B}$ is required, because one of the products of aldolase-B is glyceraldehyde, which failed to upregulate expression. It is possible that this failure is due to exogenous glyceraldehyde being gavaged in insufficient quantities or not being taken up by intestinal cells, although others 


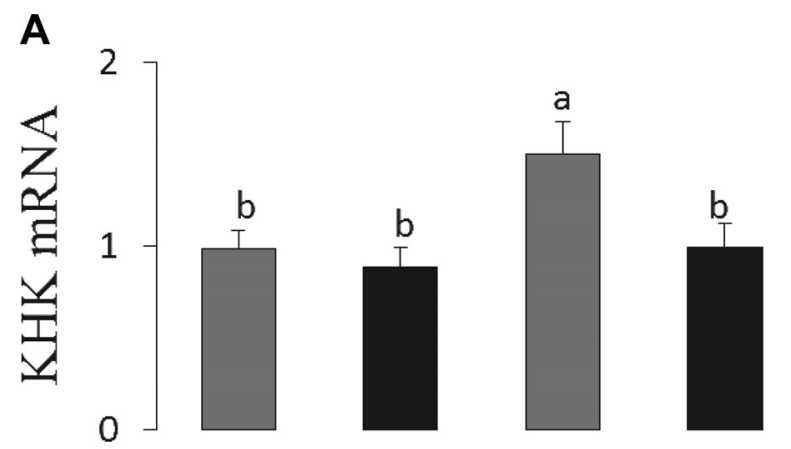

B
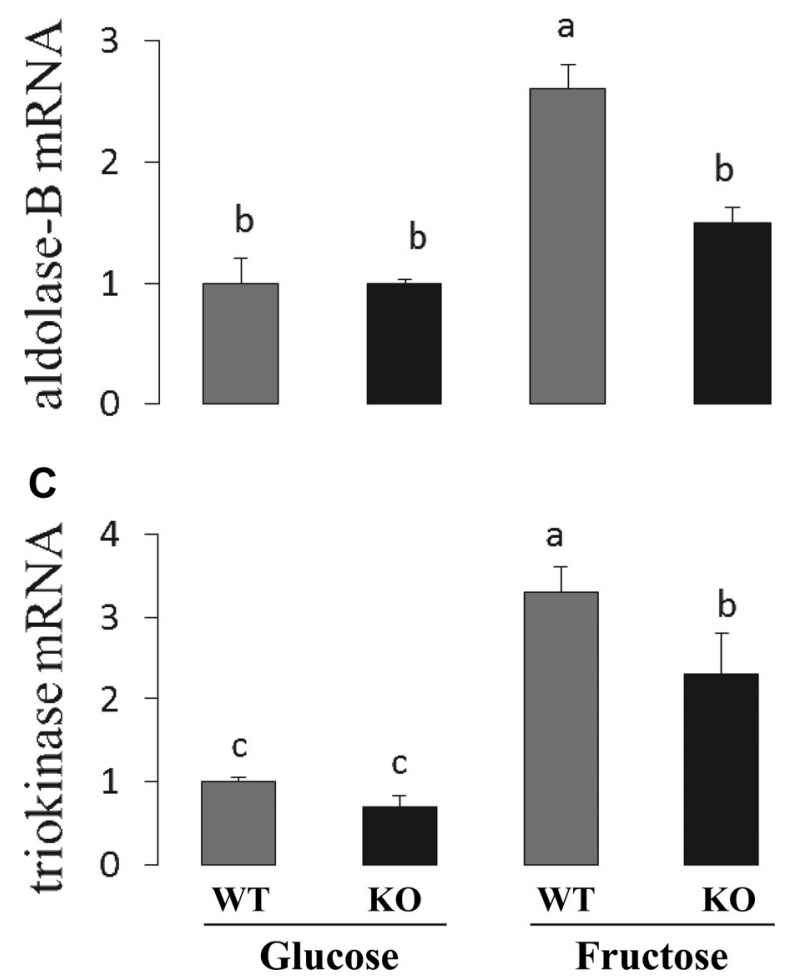

Fig. 8. Expression of fructolytic genes in Rab11 $\mathrm{a}^{\Delta \mathrm{IEC}}$ mice. Expression of KHK $(A)$, aldolase-B $(B)$, and triokinase $(C)$ was analyzed by real-time PCR in weaning WT and Rab11 $\mathrm{a}^{\Delta \mathrm{IEC}}$ mice gavaged with $30 \%$ glucose or fructose two times a day $(0.1 \mathrm{ml} / \mathrm{mouse})$ for 2.5 days. Mice were returned to dams after feeding. Results were normalized to WT mice gavaged with glucose. Bars are means \pm SE $(n=4)$, and those with different superscript letters are statistically different $(P<0.05)$ from one another as analyzed by 1-way ANOVA. Rab11a-mediated trafficking of GLUT5 to the apical membrane is required for fructose-induced regulation of genes involved in fructose metabolism.

have shown it can be transported by a saturable, competitively inhibited electrogenic and $\mathrm{Na}^{+}$-dependent transporter in the pancreas (13). The second aldolase-B product, dihydroxyacetone phosphate, and the triokinase product, glyceraldehyde 3 -phosphate, cannot be the signals because both are glycolytic intermediates and thus cannot mediate a fructose-specific response. If indeed glyceraldehyde is not the inducer, then a genetic model with aldolase-B deletion will provide a clearer conclusion and indicate that, if aldolase-B is not required, then the signal is likely a reduction in ATP levels or an increase in ADP as well as fructose 1-phosphate concentrations. KHKdependent phosphorylation of fructose in the intestine and liver is known to markedly reduce cytosolic ATP concentrations as well as reduce ATP-to-ADP ratios $(19,50)$. The intracellular location of KHK suggests that fructose may be metabolized mainly near the basolateral pole.

AMP-activated protein kinase (AMPK) kinase and AMPK are highly expressed in the small intestine (23) along with KHK and may mediate the effect of fructose, since this sugar reduces ATP-to-AMP ratios in a KHK-dependent manner (50), and AMPK is activated by reduced ATP-to-AMP ratios. Intestinal AMPK activation by 5-aminoimidazole-4-carboxamide ribonucleotide increases GLUT5 expression in the small intestine of perfused rats (Patel and Ferraris, unpublished observations). Moreover, fructose-induced activation of hepatic AMPK requires KHK (52). It is interesting to note that fructose modulation of AMPK may be confounded by gender. The expression of KHK and the activity of G-6-Pase were significantly enhanced via AMPK phosphorylation in the liver of female adult rats (52) and in the female offspring from fructose-fed dams (37). However, AMPK has also been shown to repress hepatic gluconeogenesis (31).

Because its catabolism, unlike that of glucose, to glycolytic intermediates is not subject to feedback inhibition, fructose is highly lipogenic and uricemic $(4,26)$. Our findings support the hypothesis that the biochemical basis of its pathological effects is the absence of feedback inhibition because excessive fructose feeding does not inhibit, but rather stimulates, fructolytic gene expression. Fructose feeding is known to increase cytosolic levels of three-carbon glycolytic intermediates (49) that can then be used for gluconeogenesis and acetyl-CoA, with entry in the tricarboxylic acid cycle or use in lipid synthesis. It
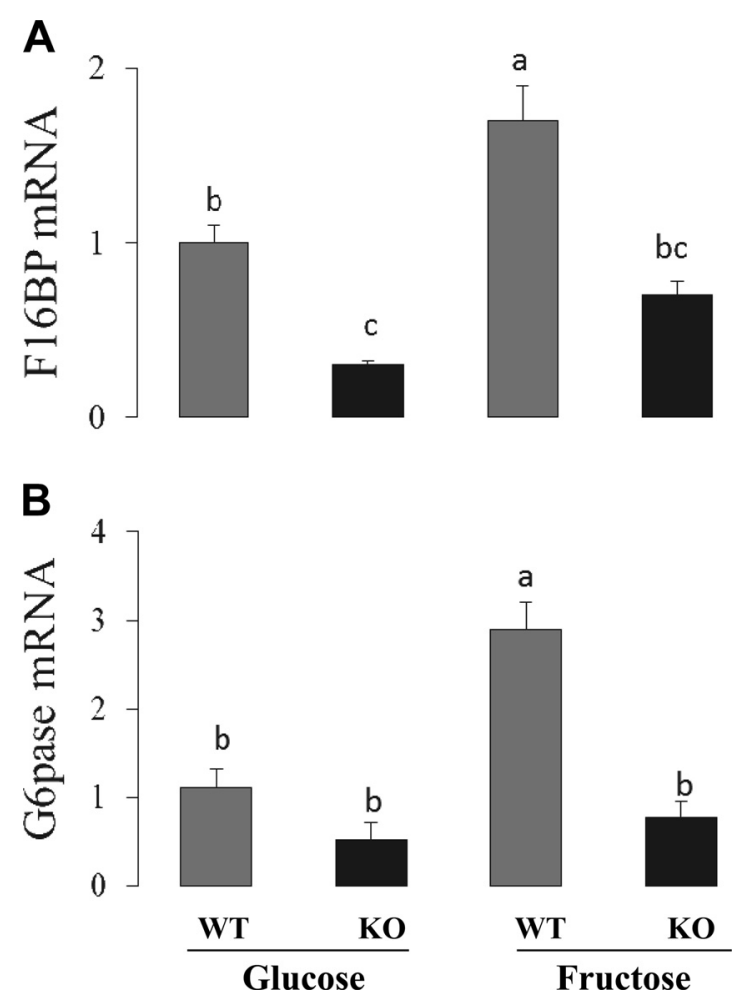

Fig. 9. Expression of gluconeogenic genes in Rab11 $\mathrm{a}^{\Delta \mathrm{IEC}}$ mice. Expression of F-1,6- $P_{2}(A)$ and G-6-Pase $(B)$ in the intestinal mucosa. Bars, normalization, and analysis are described in Fig. 8. Rab11a-mediated trafficking of GLUT5 to the apical membrane is required for fructose-induced regulation of genes involved in gluconeogenesis. 
A along villus axis

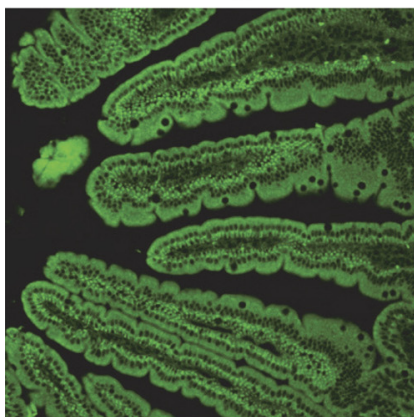

B across villus axis
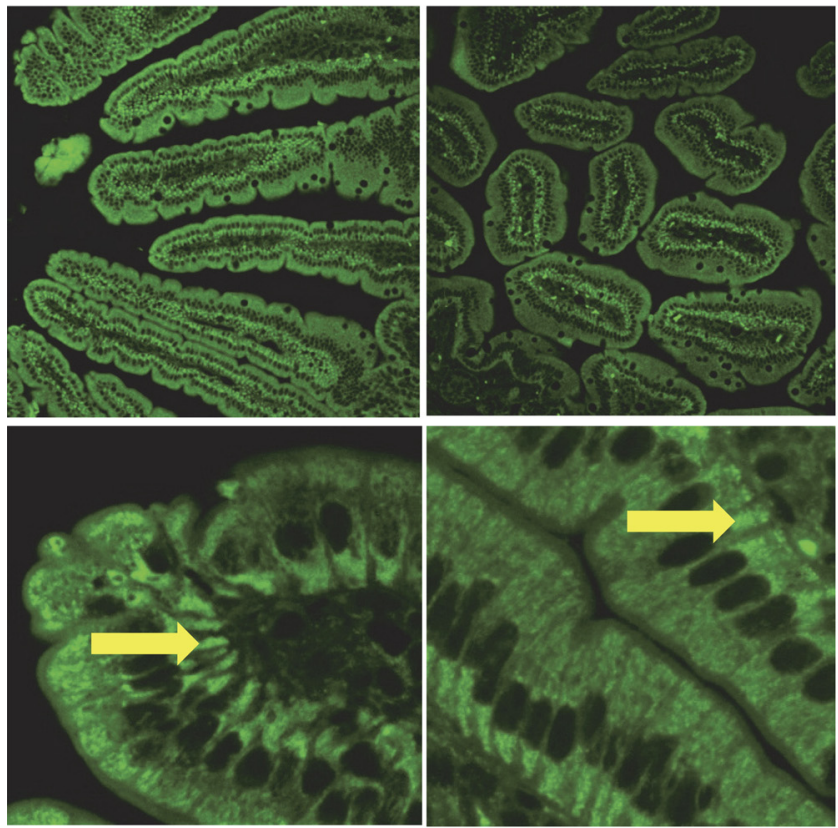

D villus tip

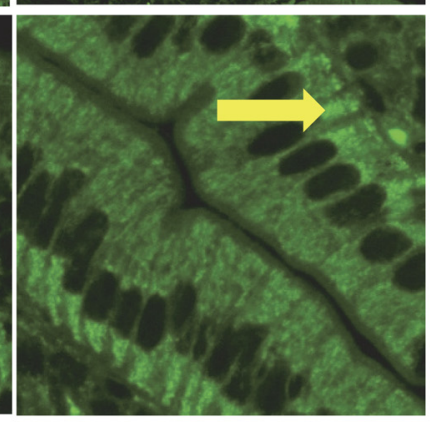

E mid villus
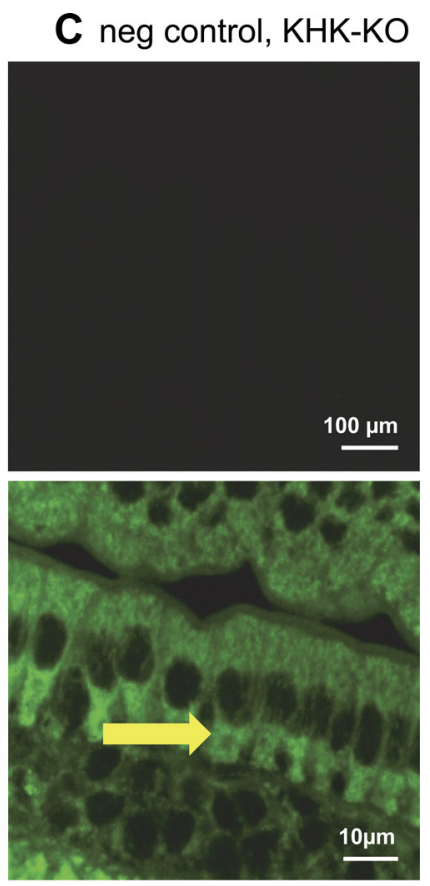

$\mathbf{F}$ villus base
Fig. 10. Distribution of KHK among cells and in the cytosol. KHK is homogeneously distributed along and across the villus axis $(A$ and $B$ ). $C$ is from a negative control slide obtained from KHK-KO mice and probed under the same antibody as those in $A$ and $B$. KHK seems to be denser below the nuclei (arrow) in most cells $(D-F)$. is likely that increased levels of these intermediates stimulate the gluconeogenic pathway because expression of the critical enzymes F-1,6- $P_{2}$ and G-6-Pase are also dramatically stimulated by dietary fructose. Fructose feeding increases blood concentrations of the triglyceride precursor glycerol (22). We did not assess intestinal expression of genes in lipogenesis, which occurs mainly in hepatic and adipose tissues.

Although the small intestine in adult mammals is thought to have a low capacity for gluconeogenic activity (41), recent studies (reviewed in Ref. 35) suggest that intestinal gluconeogenesis may contribute up to $25 \%$ of total endogenous glucose production during fasting, thereby, via the periportal neural system, modulating hunger sensations and whole body glucose homeostasis, especially between meals. Even though intestinal gluconeogenic activity is controversial, the expression levels of F-1,6- $P_{2}$ and G-6-Pase mRNA in our intestinal samples, while modest, are nevertheless significant (relatively lower than those of fructolytic genes but greater than that of hexokinase) and definitely regulated as indicated by sensitivity to luminal fructose and as we have consistently observed in previous work (11). This rapid response to luminal substrate concentration implies physiological significance. In fact, we found that chronic fructose feeding may cause KHK-dependent increases in portal glucose levels (40). Fructose also stimulates G-6-Pase and $\mathrm{F}-1,6-P_{2}$ expression in the liver of rats $(28,53)$.

Similar links between substrate metabolism and enzyme regulation have not been found for the intestine but have been demonstrated in the liver, pancreas, and kidney. Regulation of hepatic and pancreatic GLUT2 expression by glucose depends on glucose metabolism $(17,42)$, whereas that of renal glutaminase and glutamate dehydrogenase depends on glutamine metabolism $(12,39)$. Thus, in several tissues and for several enzyme systems, upregulation requires metabolism of their substrates.
It is possible that the absence of KHK (as well as GLUT5) in nonintestinal tissues may result in changes in those tissues that can nonspecifically alter fructose-inducible expression of fructolytic and gluconeogenic genes in the small intestine. This possibility is remote, however, because KHK-KO and GLUT5-KO mice were also gavage fed the control solutions lysine and glucose, which would account for these nonspecific effects.

\section{Role of Endosomal Trafficking}

There has not been any study on the role of endosomal trafficking on the regulation of cytosolic enzymes. Rab8a, Rab11, and Rab13 regulate endosomal trafficking and mediate the insertion of GLUT4 to the surface membrane of skeletal muscle in an insulindependent manner $(48,58)$. These Rabs can also regulate the sorting of membrane proteins in polarized epithelia. Thus, Rab8 mediates the anterograde trafficking of the proton-dependent peptide transporter PEPT1 and of SGLT1 from the cytosol to the intestinal apical membrane (43) while Rab11a mediates trafficking of apical proteins to the intestinal membrane (46). With reduced Rab11a-mediated GLUT5 trafficking to the apical membrane and, consequently, decreased fructose transport and metabolism in the cytosol, expression of fructolytic and gluconeogenic genes does not increase even when dietary fructose levels increase. Thus, findings in this experiment support and supplement those observed using GLUT5- and KHK-KO mice. Rab11a ablation may also reduce expression of gluconeogenic genes in glucose-gavaged Rab11 $\mathrm{a}^{\Delta \mathrm{IEC}}$ relative to WT mice because Rab8 is mislocalized in Rab11a-KO mice (46), reducing SGLT1-mediated glucose uptake.

\section{Perspectives and Significance}

Fructose uptake and metabolism by enterocytes thus contribute significantly to intestinal processing of this sugar, and 
may influence portal fructose and glucose concentrations. After high levels of dietary fructose are consumed, fructose enters the enterocyte via GLUT5, and some are metabolized by KHK in the cytosol while the remainder exits to the blood via GLUT2. The KHK-mediated step likely represents the signal that increases fructose-induced expression of fructolytic and gluconeogenic enzymes. The signal is specific, since it does not affect hexokinase I expression, and is likely dose dependent because the magnitude of fructose-induced increases is greater with 30 than $15 \%$ fructose, and because a reduction in fructose transport in Rab11 $\mathrm{a}^{\Delta \mathrm{IEC}}$ mice prevents upregulation. Moreover, we have previously shown by microarray that intestinal perfusion of fructose, but not of glucose or nonmetabolizable sugar analogs, increases G-6-Pase and F-1,6- $P_{2}$ mRNA expression (11). The intestinal response is rapid because significant increases in G-6-Pase mRNA levels are detected within $20 \mathrm{~min}$ of perfusion. Although it is clear that GLUT5 and KHK ablation completely inhibits substrate induction of fructoseresponsive genes, we are not aware of other studies that have investigated the role of regulator or effector gene heterozygosity on expression of target genes in the gut. Constitutive expression of fructolytic and gluconeogenic genes seems to be similar among WT, HZ, and KO mice for both KHK and GLUT5. Fructose-inducible expression of these genes either tends to be intermediate in heterozygous mice or to be more similar to those of GLUT5-KO and KHK-KO than to those of WT mice. Mice that are heterozygous for tumor necrosis factor AU-rich elements (ARE) (homozygous mice die postweaning) have reduced expression of a majority of bone, intestinal, and renal calcium-transporting and -binding proteins compared with those of WT, but the regulatory link between ARE and calcium homeostasis was unclear (24). The effect of heterozygous expression of regulatory or effector genes on modulation of intestinal enzymes should be studied since it is likely a source of variation in an individual's response to dietary signals.

\section{ACKNOWLEDGMENTS}

We are grateful to Drs. Elmer David, Iona Monteiro, and Eylem Topaktas as well as to Jackie Lee, Cheryl Monteiro, and Dylan Simon for help with experiments and/or for valuable discussion. We thank Drs. R. Buddington, R. Donnelly, and V. Routh for comments and suggestions.

Present addresses: V. Douard: UMR1913-MICALIS, INRA, Domaine de Vilvert, Jouy-en-Josas, France; P. Tharabenjasin, Faculty of Sport Science, Burapha University, Chon Buri, Thailand.

\section{GRANTS}

This work was supported by National Science Foundation Grants IOS1121049 and 1456673 to R. P. Ferraris. The study also received support from National Institutes of Health Grants DK-085194, DK-093809, DK-102934, and CA-178599 to N. Gao.

\section{DISCLOSURES}

No conflicts of interest, financial or otherwise, are declared by the authors.

\section{AUTHOR CONTRIBUTIONS}

Author contributions: C.R.P., V.D., and R.P.F. conception and design of research; C.R.P., V.D., S.Y., and P.T. performed experiments; C.R.P., V.D., S.Y., N.G., and R.P.F. analyzed data; C.R.P., V.D., N.G., and R.P.F. interpreted results of experiments; C.R.P. and R.P.F. prepared figures; C.R.P. and R.P.F. drafted manuscript; C.R.P., V.D., S.Y., P.T., N.G., and R.P.F. approved final version of manuscript; N.G. and R.P.F. edited and revised manuscript.

\section{REFERENCES}

1. Asipu A, Hayward BE, O'Reilly J, Bonthron DT. Properties of normal and mutant recombinant human ketohexokinases and implications for the pathogenesis of essential fructosuria. Diabetes 52: 2426-2432, 2003.

2. Barone S, Fussell SL, Singh AK, Lucas F, Xu J, Kim C, Wu X, Yu Y, Amlal H, Seidler U, Zuo J, Soleimani M. Slc2a5 (Glut5) is essential for the absorption of fructose in the intestine and generation of fructoseinduced hypertension. J Biol Chem 284: 5056-5066, 2009.

3. Bjorkman O, Crump M, Phillips RW. Intestinal metabolism of orally administered glucose and fructose in Yucatan miniature swine. J Nutr 114: 1413-1420, 1984.

4. Bray GA. How bad is fructose? Am J Clin Nutr 86: 895-896, 2007.

5. Burant CF, Saxena M. Rapid reversible substrate regulation of fructose transporter expression in rat small intestine and kidney. Am J Physiol Gastrointest Liver Physiol 267: G71-G79, 1994.

6. Cheeseman C. GLUT7: a new intestinal facilitated hexose transporter. Am J Physiol Endocrinol Metab 295: E238-E241, 2008.

7. Cheeseman CI. GLUT2 is the transporter for fructose across the rat intestinal basolateral membrane. Gastroenterology 105: 1050-1056, 1993.

8. Cirillo P, Gersch MS, Mu W, Scherer PM, Kim KM, Gesualdo L, Henderson GN, Johnson RJ, Sautin YY. Ketohexokinase-dependent metabolism of fructose induces proinflammatory mediators in proximal tubular cells. J Am Soc Nephrol 20: 545-553, 2009.

9. Crouzoulon G, Korieh A. Fructose transport by rat intestinal brush border membrane vesicles. Effect of high fructose diet followed by return to standard diet. Comp Biochem Physiol A Comp Physiol 100: 175-182, 1991.

10. Cui XL, Schlesier AM, Fisher EL, Cerqueira C, Ferraris RP. Fructoseinduced increases in neonatal rat intestinal fructose transport involve the PI3-kinase/Akt signaling pathway. Am J Physiol Gastrointest Liver Physiol 288: G1310-G1320, 2005.

11. Cui XL, Soteropoulos P, Tolias P, Ferraris RP. Fructose-responsive genes in the small intestine of neonatal rats. Physiol Genomics 18: 206-217, 2004.

12. Curthoys NP. Role of mitochondrial glutaminase in rat renal glutamine metabolism. J Nutr 131: 2491S-2497S, 2001.

13. Davies J, Tomlinson S, Elliott AC, Best L. A possible role for glyceraldehyde transport in the stimulation of HIT-T15 insulinoma cells. Biochem J 304: 295-299, 1994.

14. DeBosch BJ, Chi M, Moley KH. Glucose transporter 8 (GLUT8) regulates enterocyte fructose transport and global mammalian fructose utilization. Endocrinology 153: 4181-4191, 2012.

15. Diggle CP, Shires M, Leitch D, Brooke D, Carr IM, Markham AF, Hayward BE, Asipu A, Bonthron DT. Ketohexokinase: expression and localization of the principal fructose-metabolizing enzyme. J Histochem Cytochem 57: 763-774, 2009.

16. Douard V, Ferraris RP. The role of fructose transporters in diseases linked to excessive fructose intake. J Physiol 591: 401-414, 2013.

17. Ferrer J, Gomis R, Fernandez Alvarez J, Casamitjana R, Vilardell E. Signals derived from glucose metabolism are required for glucose regulation of pancreatic islet GLUT2 mRNA and protein. Diabetes 42: 12731280, 1993.

18. Froesch ER. Disorders of fructose metabolism. Clin Endocrinol Metab 5: 599-611, 1976.

19. Ginsburg V, Hers HG. On the conversion of fructose to glucose by guinea pig intestine. Biochim Biophys Acta 38: 427-434, 1960.

20. Gitzelmann R, Steinmann B, Tuchschmid P. Patients with hereditary fructose intolerance have normal erythrocyte aldolase activity. Clin Chim Acta 181: 163-166, 1989.

21. Golachowska MR, Hoekstra D, van ISC. Recycling endosomes in apical plasma membrane domain formation and epithelial cell polarity. Trend Cell Biol 20: 618-626, 2010.

22. Guezennec CY, Satabin P, Duforez F, Merino D, Peronnet F, Koziet J. Oxidation of corn starch, glucose, and fructose ingested before exercise. Med Sci Sports Exercise 21: 45-50, 1989.

23. Harmel E, Grenier E, Bendjoudi Ouadda A, El Chebly M, Ziv E, Beaulieu JF, Sane A, Spahis S, Laville M, Levy E. AMPK in the small intestine in normal and pathophysiological conditions. Endocrinology 155 : 873-888, 2014.

24. Huybers S, Apostolaki M, van der Eerden BC, Kollias G, Naber TH, Bindels RJ, Hoenderop JG. Murine TNF(DeltaARE) Crohn's disease model displays diminished expression of intestinal $\mathrm{Ca} 2+$ transporters. Inflamm Bowel Dis 14: 803-811, 2008. 
25. Jiang L, Lawsky H, Coloso RM, Dudley MA, Ferraris RP. Intestinal perfusion induces rapid activation of immediate-early genes in weaning rats. Am J Physiol Regul Integr Comp Physiol 281: R1274-R1282, 2001.

26. Johnson RJ, Nakagawa T, Sanchez-Lozada LG, Shafiu M, Sundaram S, Le M, Ishimoto T, Sautin YY, Lanaspa MA. Sugar, uric acid, and the etiology of diabetes and obesity. Diabetes 62: 3307-3315, 2013.

27. Kellett GL, Brot-Laroche E, Mace OJ, Leturque A. Sugar absorption in the intestine: the role of GLUT2. Ann Rev Nutr 28: 35-54, 2008.

28. Koo HY, Wallig MA, Chung BH, Nara TY, Cho BH, Nakamura MT. Dietary fructose induces a wide range of genes with distinct shift in carbohydrate and lipid metabolism in fed and fasted rat liver. Biochim Biophys Acta 1782: 341-348, 2008.

29. Korieh A, Crouzoulon G. Dietary regulation of fructose metabolism in the intestine and in the liver of the rat. Duration of the effects of a high fructose diet after the return to the standard diet. Arch Int Physiol Biochim Biophys 99: 455-460, 1991.

30. Le Gall M, Tobin V, Stolarczyk E, Dalet V, Leturque A, Brot-Laroche E. Sugar sensing by enterocytes combines polarity, membrane bound detectors and sugar metabolism. J Cell Physiol 213: 834-843, 2007.

31. Lee JM, Seo WY, Song KH, Chanda D, Kim YD, Kim DK, Lee MW, Ryu D, Kim YH, Noh JR, Lee CH, Chiang JY, Koo SH, Choi HS. AMPK-dependent repression of hepatic gluconeogenesis via disruption of CREB. CRTC2 complex by orphan nuclear receptor small heterodimer partner. J Biol Chem 285: 32182-32191, 2010.

32. Madero M, Perez-Pozo SE, Jalal D, Johnson RJ, Sanchez-Lozada LG. Dietary fructose and hypertension. Curr Hypertens Rep 13: 29-35, 2011.

33. Marriott BP, Cole N, Lee E. National estimates of dietary fructose intake increased from 1977 to 2004 in the United States. J Nutr 139: 1228S1235S, 2009.

34. Mavrias DA, Mayer RJ. Metabolism of fructose in the small intestine. 1. The effect of fructose feeding on fructose transport and metabolism in rat small intestine. Biochim Biophys Acta 291: 531-537, 1973.

35. Mithieux G, Gautier-Stein A. Intestinal glucose metabolism revisited. Diabetes Res Clin Pract 105: 295-301, 2014.

36. Moran AW, Al-Rammahi M, Zhang C, Bravo D, Calsamiglia S, Shirazi-Beechey SP. Sweet taste receptor expression in ruminant intestine and its activation by artificial sweeteners to regulate glucose absorption. $J$ Dairy Sci 97: 4955-4972, 2014.

37. Mukai Y, Ozaki H, Serita Y, Sato S. Maternal fructose intake during pregnancy modulates hepatic and hypothalamic AMP-activated protein kinase signalling in a sex-specific manner in offspring. Clin Exp Pharmacol Physiol 41: 331-337, 2014.

38. Nakayama T, Kosugi T, Gersch M, Connor T, Sanchez-Lozada LG, Lanaspa MA, Roncal C, Perez-Pozo SE, Johnson RJ, Nakagawa T. Dietary fructose causes tubulointerstitial injury in the normal rat kidney. Am J Physiol Renal Physiol 298: F712-F720, 2010.

39. Parry DM, Brosnan JT. Glutamine metabolism in the kidney during induction of, and recovery from, metabolic acidosis in the rat. Biochem $J$ 174: 387-396, 1978.

40. Patel C, Sugimoto K, Shah A, Parikh S, Douard V, Inui H, Yamanouchi T, Ferraris R. Marked hyperfructosemia without fructose-induced hyperglycemia and diabetes in fructokinase-deficient mice (Abstract). FASEB J 29: 1009.1, 2015.

41. Previs SF, Brunengraber DZ, Brunengraber H. Is there glucose production outside of the liver and kidney? Ann Rev Nutr 29: 43-57, 2009.

42. Rencurel F, Waeber G, Antoine B, Rocchiccioli F, Maulard P, Girard $\mathbf{J}$, Leturque A. Requirement of glucose metabolism for regulation of glucose transporter type 2 (GLUT2) gene expression in liver. Biochem $J$ 314: 903-909, 1996

43. Sato T, Mushiake S, Kato Y, Sato K, Sato M, Takeda N, Ozono K, Miki K, Kubo Y, Tsuji A, Harada R, Harada A. The Rab8 GTPase regulates apical protein localization in intestinal cells. Nature 448: $366-$ 369, 2007.

44. Shu R, David ES, Ferraris RP. Dietary fructose enhances intestinal fructose transport and GLUT5 expression in weaning rats. Am J Physiol Gastrointest Liver Physiol 272: G446-G453, 1997.

45. Shu R, David ES, Ferraris RP. Luminal fructose modulates fructose transport and GLUT5 expression in small intestine of weaning rats. Am J Physiol Gastrointest Liver Physiol 274: G232-G239, 1998.

46. Sobajima T, Yoshimura S, Iwano T, Kunii M, Watanabe M, Atik N, Mushiake S, Morii E, Koyama Y, Miyoshi E, Harada A. Rab11a is required for apical protein localisation in the intestine. Biol Open 4: 86-94, 2014

47. Stanhope KL, Schwarz JM, Keim NL, Griffen SC, Bremer AA, Graham JL, Hatcher B, Cox CL, Dyachenko A, Zhang W, McGahan JP, Seibert A, Krauss RM, Chiu S, Schaefer EJ, Ai M, Otokozawa S, Nakajima K, Nakano T, Beysen C, Hellerstein MK, Berglund L, Havel PJ. Consuming fructose-sweetened, not glucose-sweetened, beverages increases visceral adiposity and lipids and decreases insulin sensitivity in overweight/obese humans. J Clin Invest 119: 1322-1334, 2009.

48. Sun Y, Chiu TT, Foley KP, Bilan PJ, Klip A. Myosin Va mediates Rab8A-regulated GLUT4 vesicle exocytosis in insulin-stimulated muscle cells. Mol Biol Cell 25: 1159-1170, 2014.

49. Tappy L, Le KA. Metabolic effects of fructose and the worldwide increase in obesity. Physiol Rev 90: 23-46, 2010.

50. Tharabenjasin P, Douard V, Patel C, Krishnamra N, Johnson RJ, Zuo $\mathbf{J}$, Ferraris RP. Acute interactions between intestinal sugar and calcium transport in vitro. Am J Physiol Gastrointest Liver Physiol 306: G1-G12, 2014.

51. Vila L, Rebollo A, Adalsteisson GS, Alegret M, Merlos M, Roglans N, Laguna JC. Reduction of liver fructokinase expression and improved hepatic inflammation and metabolism in liquid fructose-fed rats after atorvastatin treatment. Toxicol Appl Pharmacol 251: 32-40, 2011.

52. Vila L, Roglans N, Perna V, Sanchez RM, Vazquez-Carrera M, Alegret M, Laguna JC. Liver AMP/ATP ratio and fructokinase expression are related to gender differences in AMPK activity and glucose intolerance in rats ingesting liquid fructose. J Nutr Biochem 22: 741-751, 2011.

53. Wei Y, Bizeau ME, Pagliassotti MJ. An acute increase in fructose concentration increases hepatic glucose-6-phosphatase mRNA via mechanisms that are independent of glycogen synthase kinase-3 in rats. $J$ Nutr 134: 545-551, 2004.

54. Wu KL, Hung CY, Chan JY, Wu CW. An increase in adenosine-5'triphosphate (ATP) content in rostral ventrolateral medulla is engaged in the high fructose diet-induced hypertension (Abstract). J Biomed Sci 21: 8, 2014 .

55. Wu X, Wang X, Gao J, Yu Y, Jia S, Zheng J, Dallos P, He DZ, Cheatham M, Zuo J. Glucose transporter 5 is undetectable in outer hair cells and does not contribute to cochlear amplification. Brain Res 1210: 20-28, 2008

56. Young RL, Chia B, Isaacs NJ, Ma J, Khoo J, Wu T, Horowitz M, Rayner CK. Disordered control of intestinal sweet taste receptor expression and glucose absorption in type 2 diabetes. Diabetes 62: 3532-3541, 2013.

57. Yu S, Nie Y, Knowles B, Sakamori R, Stypulkowski E, Patel C, Das S, Douard V, Ferraris RP, Bonder EM, Goldenring JR, Tony Ip Y, Gao N. TLR sorting by Rab11 endosomes maintains intestinal epithelialmicrobial homeostasis. EMBO J 33: 1882-1895, 2014.

58. Zeigerer A, Lampson MA, Karylowski O, Sabatini DD, Adesnik M, Ren M, McGraw TE. GLUT4 retention in adipocytes requires two intracellular insulin-regulated transport steps. Mol Biol Cell 13: 24212435, 2002. 